\title{
THE ANATOMY OF ERCOLANIA BOODLEAE (BABA, 1938) FROM SETO, KII, MIDDLE JAPAN (OPISTHOBRANCHIA : SACOGLOSSA)
}

\section{$\operatorname{AUTHOR}(\mathrm{S}):$}

Baba, Kikutaro; Hamatani, Iwao

\section{CITATION:}

Baba, Kikutaro ... [et al]. THE ANATOMY OF ERCOLANIA BOODLEAE (BABA, 1938) FROM SETO, KII, MIDDLE JAPAN (OPISTHOBRANCHIA : SACOGLOSSA). PUBLICATIONS OF THE SETO MARINE BIOLOGICAL LABORATORY 1970, 18(4): 215-219

\section{ISSUE DATE:}

1970-12-15

URL:

http://hdl.handle.net/2433/175640

RIGHT: 


\title{
THE ANATOMY OF ERCOLANIA BOODLEAE (BABA, 1938) FROM SETO, KII, MIDDLE JAPAN (OPISTHOBRANCHIA: SACOGLOSSA) ${ }^{1)}$
}

\author{
KIKUTARO̊ BABA and IwAo HAMATANI \\ Osaka Kyoiku University, Tennoji, Osaka
}

With Plates V-VII

The taxonomy of Stiliger (Stiliger) boodleae BABA, 1938 and its ecological notes inclusive of egg ribbon and veliger had been described by BABA (1938 and 1949), Baba \& Hamatani (1952) and Hamatani (1960) at different occasions. And quite recently, it was proposed to move the species under the genus Ercolania Trinchese, 1872 (Baba \& Hamatani, 1970). Thus, the genus Ercolania was restored. It has been, however, very desirable to define this genus more strictly. The present paper is prepared, for this purpose, to give an account of the anatomy of one of the species referable to Ercolania in detail.

Except for the most difficult analyzation of the genital complex on serial sections, for which the second author was responsible, the main part of the work was carried out by the first author, who wants to offer his hearty thanks to Prof. Dr. Huzio UTinomi, the Director of the Seto Marine Biological Laboratory, Kyoto University, for critical advices given him continuously for a long time of intimate intercourse. The first author wishes also to thank Mr. Robert Burn, Hon. Associate in Conchology, National Museum of Victoria, Melbourne, for the kindness to supply him with the copy of RAo's paper (1937) which was indispensable for this study and yet had long been inaccessible.

\section{Taxonomic position}

Family Hermaeidae H. \& A. Adams, 1854

Genus Ercolania TRINCHESE, 1872

Rhinophores simple (they are designated by TRINCHESE as slightly canaliculated, but actually look smooth in his explanatory figures). Characterized especially by the sabot-shaped radular teeth which are each sinuated dorsally in the middle of the

1) Contributions from the Seto Marine Biological Laboratory, No. 528.

Publ. Seto Mar. Biol. Lab., XVIII (4), 215-222, 1970. (Article 16) 
length and smooth on the ventral edge. Genital system triaulic accompanied by a spermatheca and a spermatocyst which latter may be fused with the vagina. Penis armed with a short stylet.

Type: Ercolania siotti Trinchese, 1872

In this type species the branchial papillae have each branches of liver diverticula but none of albumen glands within, and the anal papilla lies in front of the pericardial prominence.

The following is the list of 14 world species possibly referable to Ercolania: 1. E. viridis (Costa, 1866) =E. siotti TRInchese, 1872.- Mediterranean. 2. E. coerulea Trinchese, $1893=E$. costai Pruvot-Fol, 1951.- Mediterranean and Miami area. 3. E. nigra (Lemche, 1935).- Denmark. 4. E. fuscata (Gould, 1870).- Massachusetts coast. 5. E. evelinae (MArcus, 1959).- Chile. 6. E. vanella (Marcus, 1957).-, Brazil, Virginia Key and Guraçao. 7. E. talis (Marqus \& Marcus, 1956).- Brazil. 8. E. gopalai (RAo, 1937).- Madras. 9. E. nigrovittata (RAo \& RAo, 1963).- Gulf of Mannar and Palk Bay, India. 10. E. irregularis (Elıot, 1904).- Zanzibar. 11. E. varians (Eliot, 1904). - Zanzibar. 12. E. felina (Hutron, 1882).- New Zealand. 13. E. subviridis (BABA, 1959).- Toyama Bay, Japan. 14. E. boodleae (BABA, 1938).

Of these, E. gopalai is allied to E. boodleae most closely in the shape of the body, in the constitution of the radula and in many internal anatomical points, but the former is a brackish species and shows a body colouration somewhat different from that of the latter.

\section{Anatomy}

Ercolania boodleae (BABA, 1938)

(Japanese name: Arimo-umiushi)

Stiliger (Stiliger) boodleae BABA, 1938, pp. 7-8, figs. 4-5.- Seto, Kii; BABA, 1949, pp. 31, 129, pl. 7, fig. 21, text-fig. 17.-Hayama, Sagami Bay; Baba, 1959, p. 327 (list); Baba \& Hamatani, 1952, pp. 87-89, fig. 1.-Tannowa, Osaka Bay (spawning); Hamatani, 1960, pp. 59-62, figs. 1-3.- Seto,

Kii (veliger); ABE, 1964, p. 27, pl. 8, fig. 27, text-fig. 3.- From Awashima to Tsuruga Bay, Japan Sea; Usuki, 1969, p. 4.-Sado Islands (list).

Ercolania boodleae: BABA \& HAMATANI, 1970, p. 202 (change of generic name).

Distribution: Littoral, at high tide level, almost throughout the Japanese seas from Hokkaido to Kyushu (for the exact localities, see BABA, 1959, p. 327), occurring associated with such green algae as Enteromorpha, Chaetomorpha, Ulva and Boodlea. Very common in almost every locality. It is said that this species occurs also in Queensland (KENNY, 1960, p. 223; 1970, p. 85).

For this study a number of specimens were collected from the Boodlea coacta colonies in the vicinity of Seto, $\mathrm{Kii}$ at low tide in late winter to early spring, and were dissected usually under a binocular microscope while they were fresh. Of these, 
the specimens given below served for histological examinations:

$\begin{array}{ll}\text { Sp. No. 1. Jan. 27, 1950. (H.S.) } & \text { Sp. No. 5. Jan. 27, 1950. (T.S.) } \\ \text { Sp. No. 2. Jan. 27, 1950. (H.S.) } & \text { Sp. No. 6. Dec. 27, 1962. (T.S.) } \\ \text { Sp. No. 3. Jan. 10, 1952. (H.S.) } & \text { Sp. No. 7. Jan. 10, 1952. (L.S.) } \\ \text { Sp. No. 4. Feb. 13, 1950. (T.S.) } & \end{array}$

The specimens were fixed in the Bours's solution, and many sectioned preparations were stained with DELAFIELD's haematoxylin and eosin. To see the mucous contents in the tissue Sp. No. 2 was stained with azure and Sp. No. 6 with toluidine blue respectively.

External body form: The external body form and colours are already described properly by the first author (BABA, 1938 and 1949). Measurements made on a single specimen (collected at Seto, on Mar. 1, 1964) after the Code system of RissoDominguez (1963) in eolids are: total body length from rhinophores to tail tip (A) $5 \mathrm{~mm}$; length of tail (C) $2 \mathrm{~mm}$; length of rhinophores (R) $2 \mathrm{~mm}$; breadth of sole at the pericardium $(\mathrm{Bc}) 1.5 \mathrm{~mm}$; height of body at the pericardium (Hc) $1.5 \mathrm{~mm}$; and maximum length of an extended papilla $(\mathrm{Px}) 1 \mathrm{~mm}$. The largest specimens ever observed were collected at Ageshima, Sado Islands on July 11, 1968 from the Chaetomorpha moniligera colonies and attained about $15 \mathrm{~mm}$ in total length.

The rhinophores are claviform and quite simple, without any sign of an external groove (see also Bergh, 1877, p. 814; RAo, 1937, pp. 438, 447). The oral lobes on either side of the mouth are not so well marked as in Hermaeina (see Gonor, 1961, p. 88). The deciduous branchial papillae are elongated fusiform when extended but nearly conical when contracted (BABA, 1938, p. 7). They are arranged in about 7-8 oblique rows on back margins, with 2-3 papillae in each row. The liver diverticulum within each papilla gives off lateral branches which are further divided slightly more thickly than in E. gopalai. Branches of the albumen glands pass into each papilla in this species as in E. gopalai (see RAo, 1937, p. 449) and E. evelinae (see Marcus, 1959 , p. 23); in $E$. viridis there are no such branches in papillae (see Trinchese, 1872, p. 113). The anus does not form a papilla, is situated in the anterior region (not in the posterior region as stated by BABA, 1938, p. 7) of the pericardial prominence, and opens slightly on the right of the median line (cf. Trinchese, 1872, p. 90; RAo, 1937, p. 439). The nephroproct is found in a short distance behind the anus. Immediately behind and on the right side of the anus there occurs a small pore of melanin black vesicle. The pericardial prominence itself is usually oval in outline, but may be greatly elongated posteriorly.

The penial and oviducal orifices are distinct each. The former lies immediately below the right eye, and the latter is found closely behind the former. In opposition to the statements given by previous authors (i.e. Trinchese, 1872, p. 90; RAO, 1937, p. 439; Margus, 1959 , p. 23; etc.) for their species of Ercolania, the vaginal orifice in E. boodleae is completely obliterated externally (see BABA, 1968, p. 6) and in this 
species there is a marked formation of a fleshy ridge (vaginal ridge) just above the closed end of the vagina. Actually this vaginal ridge is discernible just below the two foremost rows of papillae on the right side. The foot-corners are always rounded. The whole surface of the body including the branchial papillae and sole is covered with fine cilia.

Body colour: The whole upper surface of the body excluding the anterior edge of the head, eye-regions and the foot brim is coloured dark with melanin black pigments. The distal extremity of the rhinophores is clustered with opaque white dots. The branchial papillae are also pigmented in black; in many specimens these papillae are marked each with a yellowish brown (or orange brown) cap, the tip of which is clustered with opaque white dots; very rarely the cap of papillae may be whitish and with no trace of brown pigmentation. The integument of papillae is sprinkled with a multitude of fine whitish mucous gland cells which will exude a milky fluid copiously at irritation (see also RAO, 1937, p. 438). The liver diverticula within the papillae are pale yellowish brown. A pinkish sac (= spermatheca) shines through the integument on the back behind the neck. The anal region and vaginal ridge are marked each with a whitish patch. The foot sole is colourless. In E. gopalai it is said that the body is deep brownish gray stippled with yellow, and the branchial papillae are coloured dark gray with white tips (RAO, 1937, pp. 438, 457).

Internal morphology: In $E$. viridis the descending series of the radula is spiral (Trinchese, 1872, p. 95), or it passes distally into a heap (BERGH, 1877, p. 817). Taxonomically it seems important that each of the radular teeth in $E$. viridis is indented dorsally and smooth on the ventral edge. This peculiarity of the radular teeth occurs in a series of species which are assigned to Ercolania on the preceding page. The number of teeth in a single radular ribbon seemingly varies moderately from specimen to specimen, but generally saying there are 4-6 teeth in the ascending series and 5-7 in the descending series, and the worn-out teeth are accumulated in a large or small heap (see also the aspect of the radulae shown by LemaHE, 1935, p. 136 and RAo, 1937 , p. 441). The general structure of the digestive system in $E$. boodleae is very similar to that of E. gopalai given by RAO, 1937. The oesophageal diverticulum seen in E. viridis (see Trinchese, 1872, p. 95) is absent in both E. gopalai (see RAO, 1937, p. 441) and E. boodleae. Each of the salivary glands consists of a slender band and its fine duct which is accompanied by a salivary ampulla (see Gonor, 1961, p. 90) at the point where the duct debouches into the pharynx. The fresh isolated gland cells of the liver diverticula within the branchial papillae are tinged with light grayish yellow or deep yellowish brown. The composition of the central nervous system in $E$. boodleae is practically similar to that of E. gopalai precisely shown by RAO, 1937 (p. 444). The kidney assumes a simple elongated sac situated mid-dorsally in the haemocoele (see also RAo, 1937, p. 443). A distinct reno-pericardial canal is absent (see also RAO, 1937, p. 444).

The pallial portion of the gonoduct in E. boodleae is triaulic, and the functional 
routes of various reproductive elements (autosperms, allosperms and eggs) in this species can be best understood by referring to the account and diagram of genitalia given for Limapontia (Limapontidae) by GHISelin, 1966 (p. 354, fig. 5, E). The ampulla is long and winding. The muscular vas deferens is accompanied proximally by a pair of well-developed prostate glands. The penis proper is colourless in a fresh state and conical and provided with a short recurved stylet (see also Trinchese, 1872 , p. 113; RAo, 1937, pp. 448, 459). The vagina is united with the spermatocyst (=receptaculum seminis) to form the vestibulum (- copulatory vesicle of TRINCHESE, 1872 , p. 115, and ampulla of vagina of RAo, 1937, p. 450) which matches in length with the overlying vaginal ridge. Against the statements given by Trinchese and RAO, any structure corresponding to the vaginal orifice could not be found on the surface of the vaginal ridge in E. boodleae (see again BABA, 1968, p. 6). The mucous gland is U-shaped; it debouches to the exterior via short oviduct. There is a socalled membrane gland (Pl. VII, fig. 6, n) which receives on one end ( $\mathrm{x}$ ) the conducting duct of the vagina ( 1 ) and the common duct of the albumen glands ( $k$ ) separately. The fine branches of the albumen glands pass into respective branchial papillae as noted previously. The other end ( $y$ ) of the membrane gland is connected with a large spherical organ, the spermatheca (= bursa copulatrix).

The superficial pinkish colouration of the spermatheca depends largely upon a plenty of yellowish granules deposited within the lumen of this organ. Immotile sperms may also be seen intermingled with these granules (see also Thompson \& Bebbington, 1969, p. 361 : function of gametolytic gland = spermatheca in Aplysia). In $E$. boodleae the spermatheca contains nearly always a large number of Trypanosomalike protozoans (possibly Cryptobia of the Flagellata) in various aspects of development. The copulatory action was closely observed on live animals reared in the laboratory. It was done approximately as described by RAO, 1937 (p. 451) for E. gopalai, save that the exchange of sperms in $E$. boodleae is achieved normally by mutual hypodermic injection. When a pair of individuals come to lie along each other in opposite directions for copulation, a great protrusion of the penis from the penial orifice will occur on each of them. As the vaginal orifice is practically obliterated, the tip of the protruded penis will sting the partner at any part (but most frequently at the rear part) of the integument of the vaginal ridge. This copulatory action lasts for only a moment, but it is conjectured that the sperms are injected through the stylet hypodermically into the lumen of the vaginal vestibulum at this moment.

\section{Summary}

1. Stiliger (Stiliger) boodleae BABA, 1938 is redescribed fully under the restored genus Ercolania Trinchese, 1872.

2. Situations of various orifices (i.e. anus, nephroproct, penial orifice and oviducal one) are accurately shown on the surface of the body. 
Publ. Seto Mar. Biol. Lab., XVIII (4), 1970
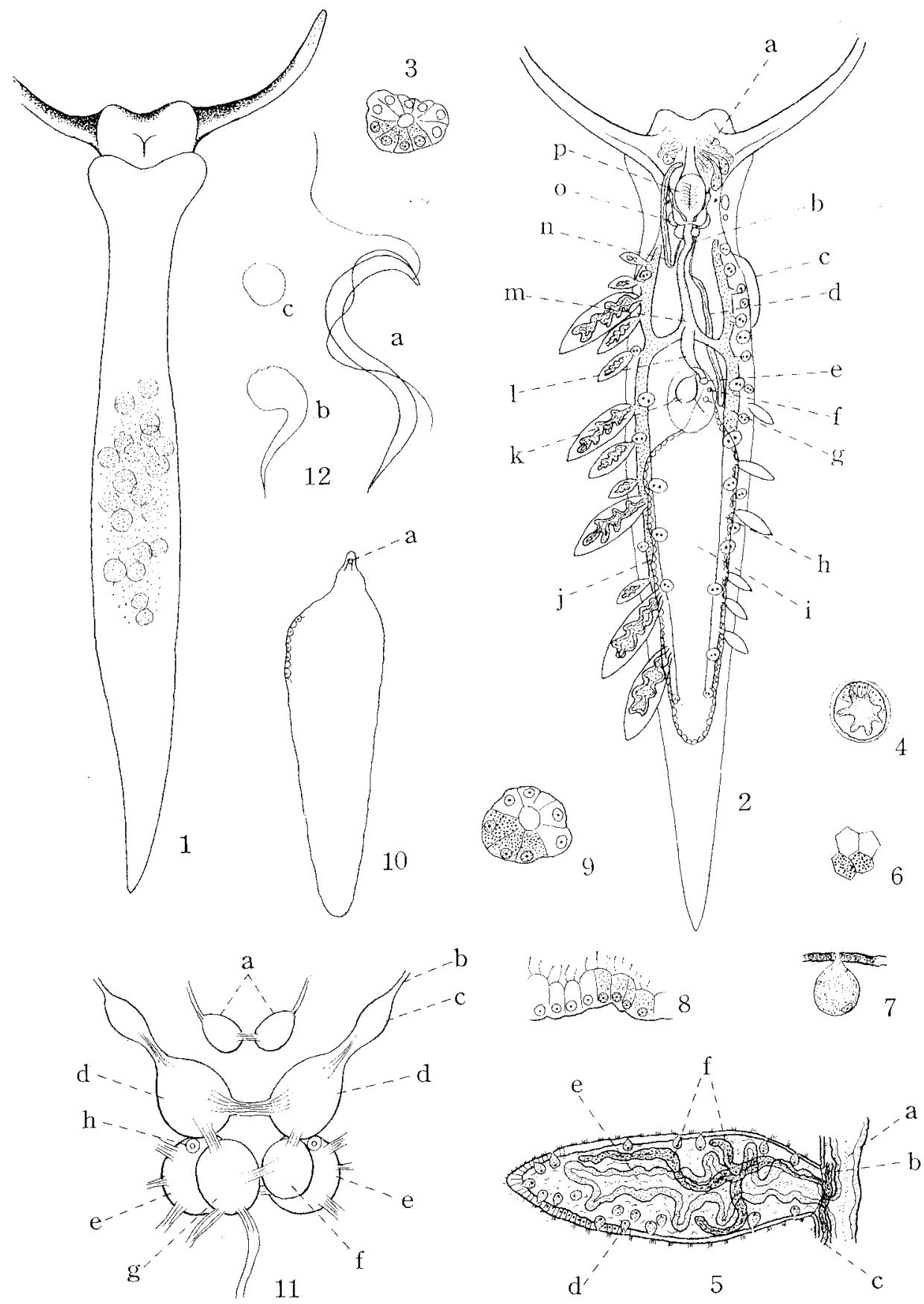

K. BabA and I. Hamatani: Anatomy of Ercolania boodleae 


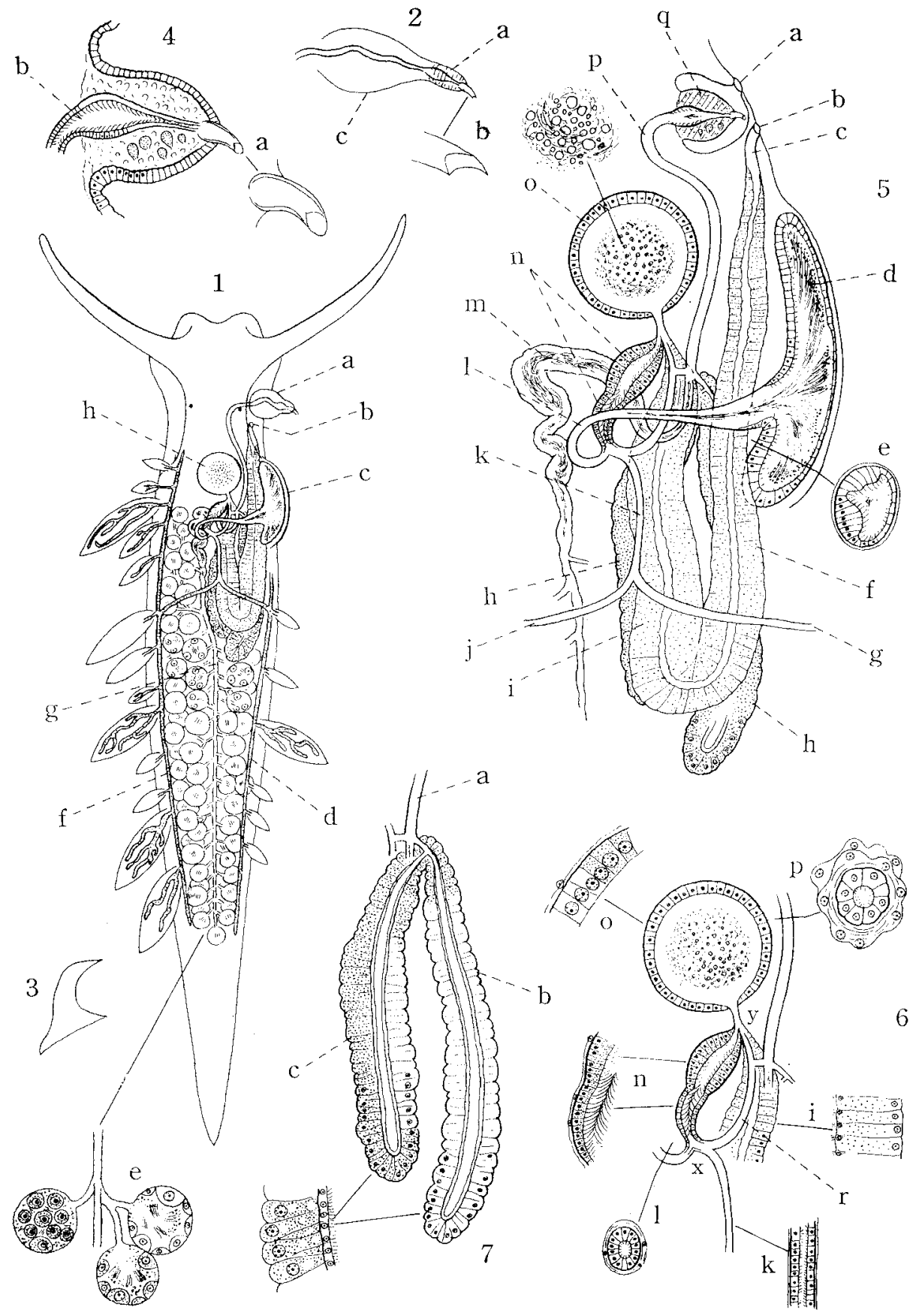

K. Baba and I. Hamatani: Anatomy of Ercolania boodleae 